\title{
Improving Students' Reading Comprehension Through KWL (Know, Want to Know, Learn) Strategy
}

Fitri Apriliana Fajri, Gunarso Susilohadi, Dwi Elyono

\author{
English Education Department \\ Teacher Training and Education Faculty \\ Sebelas Maret University of Surakarta
}

Email: fitriaprilianafajri@student.uns.ac.id

\begin{abstract}
This article is a report of a classroom action research that aimed at finding out how KWL strategy could be implemented effectively in improving the students' reading comprehension, to what extent KWL strategy could improve the students' reading comprehension, and how the classroom situation was when KWL strategy was implemented in the reading class. The classroom action research was conducted in two cycles. Each cycle comprised planning, acting, observing and reflecting. The qualitative data were collected through observations, questionnaires, and interviews while the quantitative data were obtained through tests. Some findings are obtained in this research. The first finding is that KWL strategy could be implemented effectively because of the students' ability to use their prior knowledge and activate their critical thinking to predict the text, all of which caused them to have better performance in comprehending the text. An effective way of implementing KWL strategy could be developed and applied due to a) a clear explanation of KWL steps to the students, b) the use of new and familiar topics, c) the use of visual representations of the assigned text, d) the use of group discussions and individual activities, and e) the teacher's guidance during the teaching and learning process. The second finding is that the strategy could improve the students' reading comprehension in their skills of finding main ideas, explicit information, implicit information, and word references, and understanding word meanings based on the context. The third finding is that the strategy promoted a better classroom situation.
\end{abstract}

Keywords: KWL strategy, reading comprehension, classroom situation.

\section{INTRODUCTION}

As an international language, English becomes an important language that needs to be mastered in order to make a global communication. Therefore, the Indonesian government has made English a compulsory subject, which must be learnt by the students from the beginning until advanced levels of education. Furthermore, English has been made as one of the main subjects that the students have to pass in the National Examinations. As a result, they need to master English well.
In learning English, there are four main skills to master. Those skills are listening, reading, speaking, and writing. Reading is one of the four necessary important language skills in learning English. It is the skill to support the communicative competence. Reading plays a crucial role in education as a means of assessing knowledge. The materials of teaching and learning are mostly in written form; therefore, in order to understand the teaching and learning materials, students need to improve their reading skills. 
According to Moreillon (2007), reading is an active process that requires a great deal of practice and skill. While, Grellet (1998: 7) said that reading is an active skill that constantly involves guessing, predicting, checking, and asking oneself questions. It means that a reader needs to understand not only the printed material, but also background knowledge of the subject matter discussed in the text. Fundamentally, the goal of reading is to comprehend the information conveyed in the text. Reading without understanding what has been read is useless. According to Grellet (1998: 3), reading comprehension is understanding a written text or extracting the required information from it as efficiently as possible. While Kennedy (1981: 16) states the ability of pupils to find, interpret, and use ideas is called comprehension. It can be summarized that reading comprehension is understanding the meanings of written symbols through finding, interpreting, and using ideas based on prior knowledge and experience.

The standard competence of reading that should be acquired by the tenth grade students of Senior High School is that the students are expected (1) to understand the meanings of short functional texts and essays in the forms of narrative, descriptive, and news item in their daily life, and (2) to access knowledge using their language ability. Besides, in the national standard for examination, the students are expected to be able to reach the standard competence of graduation as follows: (1) students are able to find the main ideas in written texts; (2) students are able to find stated and unstated information; (3) students are able to find references of the text; and (4) students are able to interpret the meanings of words based on the context.
However, the reading comprehension of the students was still unsatisfying. The researcher found that some students got difficulties to find the main idea in a paragraph, to identify the implicit and explicit information in a paragraph, to find references in the text, and to understand word meanings based on the context. The pre-test result showed that the students' average total score was 61.11 with the highest score 78 and the lowest score 48 . The problems occurred because of the internal and external factors. The internal factor came from the students' low motivation in learning English and the external factor came from the use of an inappropriate method of teaching and learning that was not focused on the development of reading skills and that resulted in monotonous activities that made the students less involved in the reading class.

Indeed, one of the aspects that determine the success of the learning of reading is the teaching of reading strategies. Teaching reading strategies will affect students' reading skills. Therefore, every teacher should be able to find the best strategy to accommodate their students' need. KWL is one of the instructional reading strategies used to guide students through the text. Ogle (2006) states that KWL can improve students' reading comprehension.

The letters in the name KWL stand for the process of making meanings that begins with what students Know, moves to the articulation of questions of what they Want to Know, and continues as students record what they Learn. The strategy aims to involve students actively, first, by making real the connection between their prior knowledge and the information that will be presented in the text, and, second, by 
eliciting what they know about the specific information and the ways that information is likely to be structured. According to Conner (2006: 1), this instructional strategy helps students to be able to 1) activate their prior knowledge about the topic, 2) help them in comprehending the text, 3) let them evaluate their comprehension of the text, and 4) provide an opportunity to expand the textual knowledge to the reading beyond the lines.

KWL strategy uses three column chart namely KWL Chart. Column K is used to record students' background knowledge. Column W is used to record students' prediction. Column L is used to record students' summary or conclusion about one topic. So, this strategy is able to capture the components of a teaching and learning process before, during, and after the reading. KWL helps students to explore a topic and become engaged in a meta-cognition process.

The rationale behind the use of KWL as a strategy for teaching reading skills is that KWL can function as a bridge from the abstract concepts of the text to more visible ideas that ease the reader in getting the intended meanings. It encourages students to activate their prior knowledge of the topic before doing the reading. By activating their prior knowledge, the students are helped to understand the whole text easily. It helps them get a general understanding of the text, which is one of the reading skills. KWL helps the students in setting their own purpose of reading by listing specific things they want to know about a topic. Having a purpose encourages the students to keep focused and motivated in their reading activities. Finally, the students are asked to conclude or summarize about what they have already got from the text. This is the way the students reflect what they have already learned through the text.

Considering the propositions above, the researcher thought that hypothetically KWL strategy could improve the reading comprehension of the students. Therefore, a classroom action research applying KWL strategy was conducted in the class to improve the students' reading comprehension.

The research was aimed at (1) finding out an effective implementation of KWL strategy to improve the students' reading comprehension; (2) finding out to what extent KWL strategy could improve their reading comprehension; and (3) describing the classroom situation when KWL was implemented in the reading class.

\section{RESEARCH METHODOLOGY}

The research subjects were the students of class X5, of which the number was 41 . The model of action research used in the research was the model adopted by Kemmis Mc Taggart (in Koshy 2005: 4). The model consists of four phases: 1) planning (analyzing pre-research results; making lesson plans; preparing tools for the observation of the teaching and learning process (e.g. digital camera), and preparing post-tests), 2) acting (implementing every step of KWL strategy in the classroom), 3) observing (notes are taken), and 4) reflecting (analyzing the findings continued by the process of finding out the strengths and weaknesses). The researcher used the participant type of action research because she played the roles of both an observer and a teacher in the research.

There were two types of data obtained: qualitative and quantitative data. The qualitative data were collected through 
interviews, observations, questionnaires, and documentations, while the quantitative data were gained from the students' pre-tests and post-tests. The qualitative data were analyzed by using Miles and Huberman's Interactive Model, which included data reduction, data display, and conclusion drawing or verification. While, the the quantitative data were analyzed by using Descriptive Statistics.

\section{FINDINGS AND DISCUSSION}

After implementing two cycles and making some changes of procedure in cycle 1 and cycle 2, the researcher found an effective way of implementing KWL strategy. The findings of the research show that there were some improvements of the students' performance during and after the implementation of KWL strategy. The students' ability to relate to their prior knowledge and make prediction appear to be the key factors showing the effectiveness of the implementation of KWL strategy.

The steps of teaching reading applying KWL strategy in both cycles were basically done with similar activities. At the beginning, the researcher introduced KWL strategy to the students by showing KWL chart and then demonstrating the steps, as well as giving a model in filling KWL column. The implementation of KWL strategy involved three steps. In the first step the researcher stated a topic and then showed a picture related to the topic. Then the students were asked to write any words or phrases they knew about the topic. The students recorded the words or phrases in column K. This activity trained the students to activate their prior knowledge. Prior knowledge is a key element of reading comprehension which allows students to connect with a text. As the students were able to relate to their prior knowledge, they could analyze the text more deeply. The listed words in the column helped the students to understand the main points discussed.

Having done the activity with step K, the students were asked to analyze the topic by writing the things they wanted to know. In the process of analysis, the students trained to think critically to predict the text by making questions. Creating questions would guide the students to set their purpose of reading.

In the last step, the students were given a text to read. Having read the text, the students answered their own questions and wrote them in column L. By writing down what they had learned facilitated the students in recalling the information they had used. To have a good understanding of the text, the students were trained to complete comprehension questions related to the reading indicators. The students were trained to use skimming and scanning strategies more intensively. The students then had opportunities to develop their reading skills in a scaffold supportive manner.

The researcher found some unfavorable conditions in cycle 1 . In cycle 1 the process of filling KWL columns was not optimal because the students did not have a clear understanding of the procedure of KWL strategy. The columns were designed to help the students in the process of comprehending texts by recording the process before, during, and after reading. When the students got confused about what to do with the columns, the reading comprehension process could not work well. It indicated that a clear explanation and instruction about KWL strategy were needed to help the students understand their tasks. 
In cycle 2, the researcher gave a clearer explanation by demonstrating KWL strategy and giving examples. As the students were familiar with KWL steps, they could follow the steps and use KWL columns optimally.

In addition, the situation in cycle 1 got worse when the students were not familiar with the topic. The students got difficulties in predicting the text because their limited prior knowledge. It influenced the students' attitude in the classroom. They became passive and not so motivated to join the class because of their being confused. The findings suggest that KWL strategy worked better when the students were familiar with the topic. According to Aebersold and Field (1997: 111), the process of understanding texts using the strategy will be easier when the text that students are reading is familiar and well within their proficiency. Therefore, the selection of the topic must be based on the students' level and interest. The researcher then provided appropriate reading materials in cycle 2 that could help the students in activating their prior knowledge. Besides helping the students in making prediction, the familiar topic gave a good impact on the students' activeness in the classroom, which could be seen in cycle 2. The students' activeness in expressing their ideas increased because they were familiar with the topics. Step $\mathrm{K}$ in cycle 2 done individually created a competitive atmosphere and made the classroom situation become more alive.

The use of visual representations, such as interesting pictures and videos, was helpful for the students in understanding the topic. By seeing the pictures, the students could explore their prior knowledge and predict the content of the text they would read. When the students found their predictions or assumptions were correct after reading the text, the process was transformed into building comprehension.

The group discussion in cycle 1 created a good interaction among the students. They helped each other to collect as much information as possible. Then, they generated questions by discussing together things interesting to know. The large number of members in each group made some students unable to participate in the discussion. Therefore, in cycle 2, the researcher had the students form groups of 4 or 5 members. The researcher found that small group discussions were more effective to help the students in comprehending texts.

Working with KWL chart gave the students a tool to reflect their activity before and after reading. It helped them monitor their comprehension. In fact, students did not have a basic foundation on how to monitor their reading comprehension. Therefore, the teacher's guidance in the process of teaching and learning was very important. The guidance was needed to keep the students on the right track. Duke and Pearson (2002: 212) state that teachers should monitor students' use of comprehension strategies and their success at understanding what they read. Monitoring the students during the process of teaching and learning helped the teacher observe aspects of the text which needed a further explanation to increase the students' understanding. The teacher gave feedbacks to help the students reflect what skills were unsuccessfully achieved. This way, the students could improve their reading comprehension.

It could be concluded that in implementing KWL strategy, the teacher had to make an effort to prepare appropriate materials that might help the students to activate their prior knowledge, guide them 
in every stage of KWL strategy, and lead them to be a well-comprehending reader. The sufficient prior knowledge led the students to think critically in making prediction. Together with the effective discussion and the guidance from the teacher, KWL strategy could be applied effectively to improve the students' reading comprehension.

By implementing KWL strategy in such ways, the students' reading comprehension improved. The improvement could be seen from the students' mean scores presented in the Table 1.

Table 1. The improvement of the students' mean scores in reading comprehension

\begin{tabular}{c|c|c}
\hline Pre-test & Post-test I & Post-test II \\
\hline 61.14 & 69.11 & 77.22 \\
\hline
\end{tabular}

The individual scores of the students' reading comprehension improved in every cycle after the treatment with KWL strategy. It is depicted in Chart 1.

Chart 1. Students' individual scores before and after the action

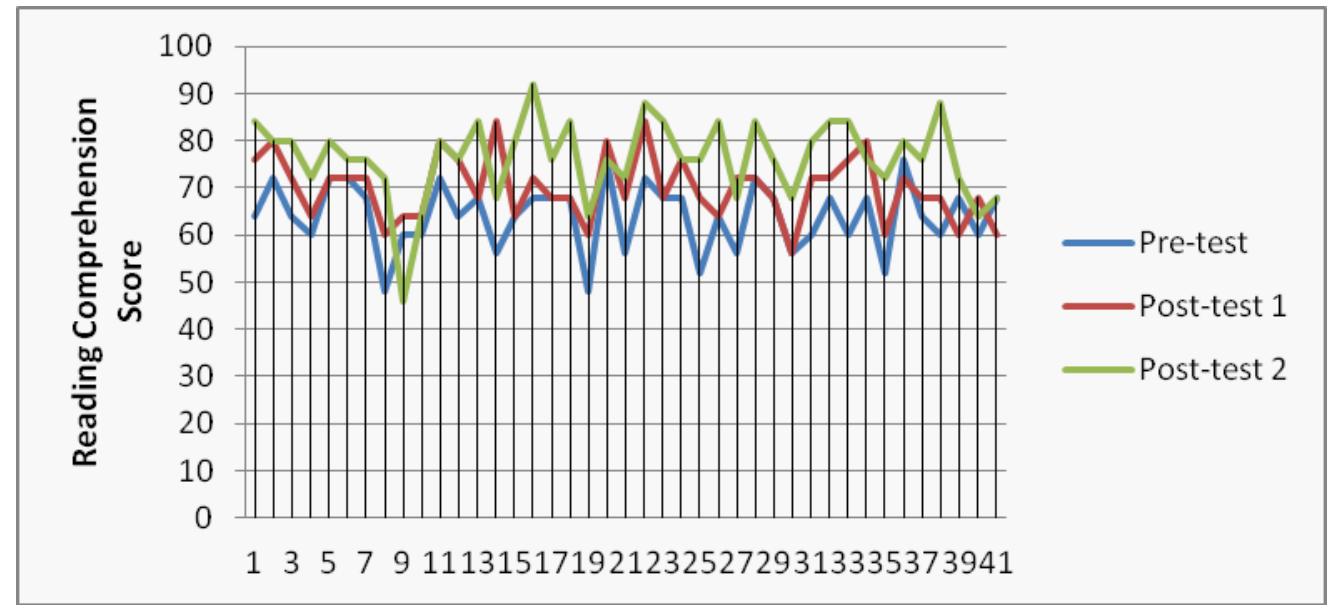

The improvement of the reading score is in line with the improvement of all indicators of reading. The improvement of students' average score viewed by the indicators of reading is depicted in the Table 2

Table 2. The students' average scores during research viewed by the reading indicators

\begin{tabular}{llccc}
\hline No & \multicolumn{1}{c}{ Indicators } & $\begin{array}{c}\text { Pre-test } \\
\text { Average Score }\end{array}$ & $\begin{array}{c}\text { Post-test 1 } \\
\text { Average Score }\end{array}$ & $\begin{array}{c}\text { Post-test 2 } \\
\text { Average Score }\end{array}$ \\
\hline 1. & Main Ideas & 59.02 & 65.37 & 76.59 \\
2. & Explicit Information & 71.43 & 78.76 & 82.93 \\
3. & Implicit Information & 56.71 & 63.41 & 71.95 \\
4. & Word References & 60.98 & 75 & 78.54 \\
5 & Word Meanings & 57.56 & 63.41 & 76.10 \\
\hline
\end{tabular}


The results above show to what extent the improvement of the students' performance can be described through the quantitative data. The students' mean scores in all indicators of reading improved and it influenced the students' reading comprehension score as a whole.

Providing pictures and exercises related to the main ideas helped the students improve their ability in finding main ideas. Seeing pictures helped the students to identify the points of the assigned topic. By practicing more in finding out the main idea of a certain paragraph, the students' skill in finding main ideas improved. Explicit information was successfully found after reading the text. The students did it in step

L. The students used skimming and scanning techniques to find the explicit information of the text faster. To have a good understanding of the text, the students were trained by reading and completing as many comprehension questions as possible.

Furthermore, in identifying implicit information of the text, the students trained to relate what was in the text to what they had already known about the topic, and then to make connection among the significant details of the text. The $\mathrm{W}$ column activity was used to train the students to identify the references of the pronouns in the text. The students also trained to scan the references of the pronouns being asked in the text. In addition, the $\mathrm{K}$ column activity could be used to train the students to practice the activity of guessing meanings of nonspecific words more often. As a result, the students' vocabulary mastery and their skill of understanding word meanings improved since they practiced understanding words in many different texts.

Implementing KWL strategy in teaching reading also promoted better classroom situations, which could be seen in the students' behavior during the process of teaching and learning. The change of the students' behavior could be seen in their active participation during the process of reading. Beginning with the step "what we know", the students did a meaningful activity to connect their own background experience related to the topic. The students showed high participation in showing their ideas during brainstorming activities.

In addition, providing media such as pictures and videos in the pre-reading activity successfully attracted the students to pay more attention during the lesson. The interesting media directed the students to be more motivated during the process of reading. The students became more enthusiastic in stating their opinions and asking questions about the topic.

Through the activities in KWL, a good communication and interaction among the students was built, when they worked in groups. The discussion session gave a chance to the students to exchange their ideas with their friends. It encouraged them to be active and brave in stating their opinions. By discussion, they also helped each other in building comprehension. In conclusion, KWL strategy provided learnercentered activities, helped build a good interaction among the students, and encouraged the students to be actively involved in the reading class, which made the classroom atmosphere more alive.

\section{CONCLUSION AND SUGGESTION}

This research was aimed at (1) finding out an effective way of implementing KWL strategy to improve the students' reading comprehension, finding out to what extent the strategy could improve the students' reading comprehension, and (3) to describe how the 
situation was when KWL strategy was implemented in the classroom. It was conducted in class X5 SMA of Muhammadiyah 1 Karanganyar in the academic year of 2014/2015.

The results of the research show that KWL strategy could be implemented effectively due to the students' ability to use their prior knowledge and activate their critical thinking to predict the text, so that they performed better in comprehending the text. The researcher succeeded in developing an effective way of implementing KWL strategy by applying several ways: (a) providing a clear explanation of KWL steps to the students, (b) providing new and familiar topics, (c) providing visual representations of the text, (d) conducting group discussions and individual activities, and (e) providing guidance during the teaching and learning process.

By implementing KWL strategy in such ways, the students' reading comprehension improved. The students' mean score in pre-test was 61.14. It increased to 69.11 in post-test I and 77.22 in post-test II. The strategy could also improve their skills of finding main ideas, explicit and implicit information, and word references, and their skill of understanding word meanings based on the context.

Implementing KWL strategy in the reading class promoted a better classroom situation. The classroom condition before the research, which used a traditional method, trapped the students in a monotonous activity and resulted in their less involvement in the process of learning. After the implementation of KWL strategy, which provided learner-centered activities, a good interaction among the students could be built and the students showed their active involvement in the reading class, which made the classroom atmosphere more alive.

In conclusion, KWL strategy not only facilitated the students to have better comprehension in reading but also promoted a better classroom situation. Consequently, it is recommended that English teachers apply KWL as an alternative strategy in teaching reading. It should be noted that, in its implementation, KWL strategy should be accompanied with well-prepared materials and media to help the students achieve the goal of reading comprehension.

\section{BIBLIOGRAPHY}

Aebersold, J.A and Field, M.L (1997), From reader to reading teacher. New York: Cambridge University Press.

Duke, Nell.K \& Pearson, David.P. (2002). What teacher had to say about reading instruction third edition. International Reading Association

Grellet, Francoise. (1998). Developing reading skills. United Kingdom: Cambridge University Press

Kennedy, Eddie C. (1981). Methods in teaching developmental reading second edition. Englewood: F. E. Peacock Publishers, Inc.

Koshy, V. (2005). Action Research for improving practice a practical guide. Trowbridge, Wiltshire, Great Britain: Cromwell Press.

Moreillon, Judi. (2007). Collaborative strategies for teaching reading comprehension. USA: American Library Association.

Ogle, D. (2006). KWL: A teaching model that develops active reading of expository text. The Reading Teacher, 40, 564-570. 
Conner, Jennifer. (2006). Instructional reading strategy: KWL (Know, Want to Learn, Learned). Retrieved February, 16, 2011, from http://www.indiana.edu/ 1517/KWL. htm 